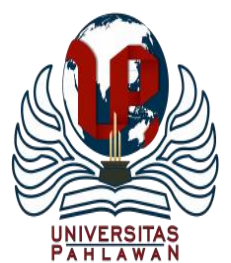

Edukatif : Jurnal Ilmu Pendidikan Volume 3 Nomor 5 Tahun 2021 Halm 2079 - 2091

EDUKATIF: JURNAL ILMU PENDIDIKAN

Research \& Learning in Education

https://edukatif.org/index.php/edukatif/index

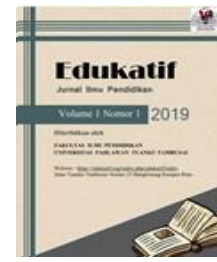

\title{
Pengaruh Penggunaan Learning Management System Google Classroom dan Gaya Mengajar Guru terhadap Motivasi Belajar pada Pembelajaran Daring
}

\author{
Nungki Khunaini ${ }^{1 凶}$, Ni’matush Sholikhah ${ }^{2}$ \\ Universitas Negeri Surabaya, Indonesia ${ }^{1,2}$ \\ E-mail : nungki.17080554023@ mhs.unesa.ac.id ${ }^{1}$, nimatushsholikhah@unesa.ac.id $^{2}$
}

\begin{abstract}
Abstrak
Adanya pandemi covid 19 memunculkan kebijakan pembelajaran daring. Sehingga kegiatan pembelajaran sebagaian menggunakan Learning Management System (LMS), salah satunya google classroom. Tujuan pada penelitian ini yaitu untuk mengetahui 1) pengaruh antara google classroom terhadap motivasi belajar siswa XI IPS MAN 2 Nganjuk 2) pengaruh antara gaya mengajar guru terhadap motivasi belajar siswa XI IPS MAN 2 Nganjuk 3) pengaruh antara google classroom dan gaya mengajar guru terhadap motivasi belajar XI IPS MAN 2 Nganjuk. Jenis penelitian ini adalah korelasional dengan pendekatan kuantitatif. Teknik pengumpulan data menggunakan wawancara dan Kuisioner yang disebar secara online. Teknik analisis data menggunakan analisis regresi linier berganda. Hasil penelitian menyatakan 1) tidak terdapat pengaruh signifikan variabel google classroom terhadap motivasi belajar 2) terdapat pengaruh signifikan dan positif variabel gaya mengajar guru terhadap motivasi belajar 3) terdapat pengaruh signifikan secara bersama sama variabel google classroom dan gaya mengajar guru terhadap motivasi belajar. Gaya mengajar personalisasi dan interkasional adalah gaya mengajar yang dominan digunakan dan memberikan dampak yang baik bagi siswa.
\end{abstract}

Kata Kunci: Google Classroom, Gaya Mengajar Guru, Motivasi Belajar.

\section{Abstract}

There was a covid 19 pandemic that showed a daunting learning policy. So the learning activity as a use Learning Management System (LMS), one of which is google classroom. The purpose of this research is to find out 1) the effect between google classroom on student motivation XI IPS MAN 2 Nganjuk 2) the effect between teacher teaching style on student motivation 3) the effect between google classroom and teacher teaching style motivation XI IPS MAN 2 Nganjuk. This kind of research is corelated wuth quantitative approaches. Data gathering techniques use interviews and quizer that are distributed online. Data analysis technique using multiple linier regresion analysis. Research resukt stated 1) there is No. positive and significant influence between the google classroom and motivation to learn 2) there is a positif and significant influence between the teacher tecahing style and the motivation to learn 3) this a positive and significant influence between the google classroom and the teacher teaching style. Personalized and interactive teaching style are the dominant teaching used and have a good impact on student.

Keywords: google classroom, teacher teaching style, motivation learning.

Copyright (c) 2021 Nungki Khunaini, Ni'matush Sholikhah

$\triangle$ Corresponding author

Email : nungki.17080554023@mhs.unesa.ac.id

DOI : https://doi.org/10.31004/edukatif.v3i5.737

ISSN 2656-8063 (Media Cetak)

ISSN 2656-8071 (Media Online) 
2080 Pengaruh Penggunaan Learning Management System Google Classroom dan Gaya Mengajar Guru Terhadap Motivasi Belajar Pada Pembelajaran Daring - Nungki Khunaini , Ni'matush Sholikhah DOI: https://doi.org/10.31004/edukatif.v3i5.737

\section{PENDAHULUAN}

Pendidikan dan manusia adalah suatu hal yang sangat sulit terpisahkan, karena pendidikan memiliki peran dalam berkembangnya pengetahuan manusia. Pembelajaran adalah salah satu bagian dari pendidikan. Belajar adalah proses dua arah yang terjadi diantara guru sebagai soerang pembimbing dan siswa sebagai seorang yang terbimbing, sehingga peserta didik memerlukan umpan balik dari guru demikian pula sebaliknya agar pembelajaran berlangsung efektif (Rikizaputra et al., 2020). Proses pembelajaran bertujuan untuk membawa sebuah perubahan terhadap peserta didik secara terprogram untuk mengembangkan potensi yang dimiliki (Harahap et al., 2021). Pandemi Covid 19 yang mulai melanda Indonesia menyebabkan pemerintah mengambil berbagai tindakan, khususnya Kementerian Pendidikan dan Kebudayaan (Kemendikbud) mengeluarkan sebuah peraturan untuk belajar dirumah sejak Maret 2020. Sistem pendidikan yang semulanya tatap muka diubah menjadi pembelajaran daring atau jarak jauh. Menurut (Daheri et al., 2020) mengungkapkan bahwa pelaksanaan pembelajaran daring membutuhkan usaha yang cukup besar dari guru maupun dari orang tua sebagai lingkungan pertama siswa dirumah, dan tentunya membutuhkan kerjasama diantara keduanya. Menurut Ferrer \& Kirschning dalam (Alfina, 2020) Penerapan pembelajaran jarak jauh akan membawa dampak yang baik bagi konten digital karena akan lebih mudah diakses oleh siswa secara fleksibel, seperti adanya kolaborasi pembelajaran secara daring (Online Learning Collaboration).

Guru merupakan tonggak dan juga pendorong dalam kegiatan pemberlajaran. Guru adalah salah satu bagian dari pembelajaran, dan memiliki peran yang penting didalamnya. Guru merupakan bagian dari beberapa faktor eksternal yang memiliki dampak terhadap peningkatan motivasi pada belajar peserta didik. Seperti yang diungkapkan oleh Sadirman (2016) satu dari beberapa faktor yang dapat mempengaruhi tingkat motivasi belajar pada peserta didik yaitu peran guru, dalam hal ini peran seorang guru dalam proses pembalajaran yaitu upaya gaya mengajar yang dilakukan oleh guru. Sebagai seorang guru tentu memiliki kemampuan dalam mengelola kelas maka dari itu guru harus menarik minat peserta didik dengan segala kemampuan yang dimilikinya, selain itu guru dengan segala kemampuannya juga harus membantu siswa berkembang dengan baik di bidang akademik maupun di bidang non akademik agar dapat terus maju. Pada proses pembelajaran, tentu guru memiliki cara mengajar yang berbeda-beda yang digunakan, seperti cara penyampaian materi, interaksi terhadap peserta didik, maupun penggunaan media yang dipilih sebagai penunjang pembelajaran. Pada pembelajaran daring, media yang digunakan sebagai penunjang pembelajaran beralih menggunakan aplilkasi online yang dapat digunakan untuk mempermudah selama kegaiatan pembelajaran daring berlangsung. Salah satu aplikasi pembelajaran online yang mampu digunakan kedalam ranah dunia pendidikan yaitu Learning Management System (LMS), adapun beberapa LMS yang digunakan selama pembelajarn daring yaitu Moodle, Google Classroom, Edmodo, dan Schoology.

Dari hasil studi awal penelitian yang dilakukan dengan wawancara di MAN 2 Nganjuk didapatkan informasi bahwa semenjak pembelajaran daring berlangsung membuat guru maupun peserta didik beradaptasi dengan hal tersebut. Terutama dalam penggunaan platform selama pembelajaran daring. Dari masing-masing guru menggunakan platform yang berbeda-beda, agar peserta didik dapat memahami materi yang dipaparkan melalui platform dengan baik perlu adanya pertimbangan dari guru dalam pemilihan platform yang akan digunakan. Dan platform Google Classroom lebih sering digunakan selama pembelajaran daring. Peran seorang guru dalam proses pembalajaran yaitu upaya gaya mengajar yang dilakukan oleh guru, yang terjadi di MAN 2 Nganjuk adalah masing-masing individu guru memiliki gaya mengajar yang bervariasi, ada sebagian guru yang memberikan materi untuk dipelajari sendiri kemudian memberikan soal evaluasi, adapula guru yang memberikan materi dan dijelaskan terlebih dahulu kemudian baru memberikan soal evaluasi. Dengan adanya permasalahan tersebut, guru memiliki tantangan untuk menggunakan cara mengajar yang dirasa nyaman yang pada akhirnya memberikan kemudahan bagi peserta didik untuk mengumpulkan tugas ataupun menyerap materi yang telah dipaparkan. Tentunya jika peserta didik merasa nyaman dan dengan mudah menyerap 
2081 Pengaruh Penggunaan Learning Management System Google Classroom dan Gaya Mengajar Guru Terhadap Motivasi Belajar Pada Pembelajaran Daring - Nungki Khunaini , Ni'matush Sholikhah DOI: https://doi.org/10.31004/edukatif.v3i5.737

materi yang disampaikan akan memberikan kemudahan mengerjakan tugas dan peserta didik akan lebih tertarik dan bersemangat mengikuti pembelajaran (Astutie, 2003).

Pada kondisi yang terjadi, peserta didik mengalami permasalahan dalam pengumpulan tugas, Ada peserta didik yang mengumpulkan tugas tepat pada batas waktu yang telah diberikan dan tidak sedikit pula peserta didik tidak mengumpulkan tugas pada batas waktu yang telah diberikan. Bahkan yang terjadi Guru sampai harus menghubungi peserta didik satu persatu pada saat batas terakhir pengumpulan agar peserta didik mengumpulkan tugas yang telah diberikan. Adanya permasalahan pada yang dialami siswa kelas XI IPS MAN 2 Nganjuk, dapat disimpulkan bahwa sebagian dari peserta didik di MAN 2 Nganjuk memiliki motivasi belajar yang rendah. Hal tersebut berdasarkan indikator siswa memiliki motivasi dalam belajar yang dipaparkan oleh (Suprihatin, 2015) salah satunya yaitu tekun dalam mengerjakan tugas. Sedangkan kondisi yang terjadi sebagian siswa memiliki permasalahan dalam pengerjaan dan pengumpulan tugas yang kurang tepat waktu pada saat batas waktu yang telah ditentukan. Hal tersebut menunjukkan bahwa tidak secara keseluruhan peserta didik memiliki tingkat motivasi untuk belajar yang tinggi.

Dari permasalahan diatas, peneliti perlu memerlukan penelitian berpengaruhnya penggunaan google clasroom dan gaya mengajar yang digunakan guru terhadap motivasi belajar siswa selama pembelajaran daring. Penelitian ini bertujuan untuk mengetahui adanya pengaruh signifikan yang terjadi antara penggunaan google classroom terjadap motivasi belajar siswa pada pembelajaran daring, adanya pengaruh gaya mengajar yang digunakan oleh guru terhadap motivasi pembelajaran daring pada pembelajaran daring, serta pengaruh stimultan yang terjadi antara penggunaan google classroom dan gaya mengajar guru terhadap motivasi belajar pada pembelajaran daring.

Google Classroom merupakan salah satu jenis Learning Management System (LMS) yang berguna dalam proses pembalajaran dan sangat membantu karena memberikan kemudahan bagi penggunanya, selain itu google classroom dapat memberikan dampak kemudahan bagi seorang guru dalam memberikan penyampaian sebuah materi kepada siswa (Shaharanee et al., 2016). Kelebihan-kelebihan yang disajikan oleh google classroom memberikan kemudahan bagi guru maupun siswa dalam kegiatan pembelajaran. salah satu kelebihan yang dimiliki google classroom yaitu dapat digunakan sebagai ruang kelas sehingga dapat mempermudah guru dalam memberikan tugas ataupun mempermudah peserta didik dalam pengumpulan tugas (Destyana \& Surjanti, 2021). Indikator dari google classroom yaitu aspek bahasa, aspek penyajian google classsroom, aspek kemudahan (Ratnawati \& Sulisworo, 2021).

Guru perlu menggunakan metode gaya dalam mengajar untuk mengimplementasikan tugasnya sebagai seorang pendidik, karena gaya mengajar guru merupakan cara yang dilakukan oleh guru untuk menyampaikan materi agar tercapainya tujuan pembelajaran yang diinginkan (Djauhari, 2016). Menurut Ali (2004) Gaya mengajar adalah gaya yamg disampaikan guru dalam pembelajaran merupakan cerminan sebuah pengajaran dengan caranya sendiri. Tonggak keberhasilan siswa adalah salah satunya terletak pada seroang guru Oleh karena itu gaya mengajar guru sangat penting karena memiliki pengaruh terhadap keberhasilan belajar, dengan demikian Gaya mengajar yang digunakan guru dapat menentukan keberhasilan dalam kegiatan pendidikan (Rahman, 2016). Indikator pada gaya mengajar guru yaitu gaya mengajar klasik, gaya mengajar interaksional, gaya mengajar personalisasi, gaya mengajar teknologis (Cahya, 2020).

Permasalahan motivasi belajar kerap menghampiri siswa, terutama pada saat siswa mengalami kesilitan dalam mengerjakan tugas (Cahya, 2020). Maka dari itu motivasi dalam pembelajaran penting bagi guru dan peserta didik. Pada masa pembelajaran daring motivasi sangat dibutuhkan karena lingkungan belajar bergantung pada motivasi dan karaktersitik masing-masing individu terkait rasa ingin tahu dengan pembelajaran (Fitriyani et al., 2020). Motivasi belajar merupakan sebuah energi perubahan yang telah muncul pada diri seseorang dengan adanya perasaan untuk menggapai sebuah tujuan, dengan demikian adanya perubahan pada diri seseorang secara disadari maupun tidak merupakan pertanda adanya motivasi pada diri 
2082 Pengaruh Penggunaan Learning Management System Google Classroom dan Gaya Mengajar Guru Terhadap Motivasi Belajar Pada Pembelajaran Daring - Nungki Khunaini , Ni'matush Sholikhah DOI: https://doi.org/10.31004/edukatif.v3i5.737

seseorang (Emda, 2017). Indikator dari motivasi belajar terdiri dari motivasi instrinsik dan motivasi ekstrnsik (Cahya, 2020).

Penerapan Google Classroom pada kegiatan pembelajaran dapat mendukung membantu peningkatan motivasi belajar pada siswa, hal tersebut dikarenakan guru menjadi lebih mudah dalam mendistribusikan tugas kepada peserta didik dan menilai tugas begitupula dengan peserta didik juga lebih mudah mengumpulkan tugas. Hal tersebut sejalan dengan sebuah penelitian Rikizaputra et al. (2020) yang mengungkapkan adanya pengaruh diterapkannya Google Classroom secara positif dan signifikan terhadap motivasi belajar. Adapun perbedaan penelitian lain yang dilakukan oleh (Azhar \& Iqbal, 2018) yang mengungkapkan bahwa google classroom tidak efektif digunakan dalam kegiatan pembelajaran. Sementara itu penelitian (Putri et al., 2019) yang mengungkapan gaya mengajar guru berpengaruh memiliki pengaruh dengan tingkat motivasi belajar siswa. Namun terdapat perbedaan dengan penelitian (Putri et al., 2019) yang dilakukan pada pembelajaran tatap muka, sedangkan pada penelitian ini diterapkannya pembelajaran daring dari adanya pandemi covid 19. Pada penelitian variabel-variabel yang yang digunakan belum pernah diteliti secara bersama-sama pada penelitian sebelumnya.

\section{METODE PENELITIAN}

Jenis penelitian ini adalah penelitian kuantitatif yaitu sebuah penelitian yang menggunakan data kuantitatif didalamnya, penelitian kuantitatif dilandaskan pada asumsi yang realistis (Kurniawan, 2018). Penelitian ini bersifat korelasional (hubungan), menurut Kurniawan (2018) penelitian korelasional (hubungan) atau asosiatif adalah penelitian untuk mencari suatu sebuah hubungan yang tejadi dari dua variabel yang digunakan atau lebih dan untuk mengetahui tingginya pengaruh dari variabel yang digunakan pada penelitian. Penelitian ini memiliki sebuah tujuan yaitu untuk mengetahui danya hubungan dari variabel Google Classroom (X1) dan Gaya Mengajar Guru (X2) terhadap Motivasi Belajar (Y). Populasi yang digunakan sebagai subjek pada penelitian ini adalah peserta didik kelas XI IPS MAN 2 Nganjuk berjumlah 106 peserta didik. Sampel pada penelitian ini diambil menggunakan rumus Slovin yaitu :

$$
n=\frac{N}{1+N e^{2}}
$$

Sehingga memperoleh hasil 84 peserta didik sebagai sampel penelitian dan diperoleh dengan menggunakan teknik sampling Simpel Random Sampling. Teknik pengumpulan data pada penelitian ini yaitu 1) Angket atau Kuisioner, merupakan teknik pengumpulan data dengan berisi beberapa pertanyaan yang akan diajukan kepada responden yang dituju untuk mendapatkan data berupa jawaban dari rumusan permasalah yang diajukan oleh peneliti, dan 2) Wawancara, yaitu sebuah dialog yang terjadi antara pewawancara dan yang diwawancarai untuk memperoleh sebuah informasi perihal permasalahan-permasalahn yang sedang dihadapi di kelas XI IPS MAN 2 Nganjuk.

Teknik analisis data menggunakan aplikasi SPSS 25 yang terlebih dahulu melakukan uji validitas dan reabilitas bertujuan untuk mengetahui valid tidaknya sebuah instrumen dan hasil konsisten pada sebuah data meskipun diteliti oleh peneliti yang berbeda (Kurniawan, 2018). Dengan indikator variabel sebagai berikut :

Tabel 1 Indikator Variabel

\begin{tabular}{ll}
\hline Variabel & Indikator \\
\hline Google Classroom & Aspek Bahasa, Aspek Penyajian \\
Sumber : (Ratnawati \& Sulisworo, & Google Classroom, dan Aspek \\
2021)) & Kemudahan Googel Classroom \\
\hline Gaya Mengajar Guru & Gaya Mengajar Guru Yaitu Gaya \\
Sumber : (Cahya, 2020) & Mengajar Klasik, Gaya Mengajar \\
& Personalisasi, Gaya Mengajar, \\
\hline
\end{tabular}




\begin{tabular}{lll}
\hline & $\begin{array}{l}\text { Interaksional, Dan Gaya Mengajar } \\
\text { Teknologis }\end{array}$ & \\
& Motivasi Instrinsik dan Motivasi \\
\hline Motivasi Belajar & Ekstrinsik. & \\
Sumber : (Cahya, 2020) & &
\end{tabular}

Data yang didapatkan dari penelitian yang telah dilakukan merupakan data ordinal yang mana bersumber dari kuisioner yang menggunakan skala Likert yang berskor 1-5. Agar bisa dilakukan uji selanjutnya, data ordinal tersebut harus diubah menjadi data interval dengan teknik Method of Successive Interval (MSI) dengan Microsoft Excel, yaitu metode pengskalaan yang digunakan dalam mentransformasi skala pengukuran berbentuk ordinal kedalam skala pengukuran berbentuk Interval (Sedarmayanti \& Hidayat, 2011). Setelah itu dilakukan Analisis Regresi Linier Berganda yang terdiri dari Uji Asumsi Klasik yang terdiri dari 1) Uji Normalitas bertujuan megetahui normal atau tidaknya model regresi dari variabel bebas dan variabel terikat, 2) Uji Heteroskedastisitas bertujuan mengetahui apakah ada ketidaksamaan variance dan residual dalam model regresi dan 3) Uji Multikolinieritas digunakan untuk mengetahui adanya korelasi apa tidak dari model regresi. Untuk mengetahui hasilnya dapat dilihat dari nilai VIF atau nilai tolerance yang dihasilkan. Uji hipotesis dilakukan dengan Uji $\mathrm{T}$ yaitu menjelaskan tentang seberapa jauh pengaruh satu variabel independen yang dapat menerangkan variasi pada variabel independen dan Uji $\mathrm{F}$ yaitu digunakan untuk mengetahui ada tidaknya pengaruh dari variabel independen yang diteliti secara simultan terhadap variabel dependen yang diteliti (Ghozali, 2013). Kemudian (Kurniawan, 2018). Dan Uji Koefisien Determinasi bertujuan mengetahui s kemampuan dari sebuah bentuk regresi dengan mengetahui adanya variasi dari variabel dependen.

\section{HASIL DAN PEMBAHASAN PENELITIAN}

Penelitian ini bertempat di MAN 2 Nganjuk yang merupakan salah satu sekolah dimana kegiatan pembelajarannya menggunakan salah satu Learning Management System yaitu google classroom. Subjek yang dituju yaitu kelas X1 IPS MAN 2 Nganjuk. Berdasarkan proses penelitian dengan penyebaran kuisioner secara online, diperoleh data dari 86 respoden peserta didik di kelas XI IPS MAN 2 Nganjuk. Pada penelitian ini menggunakan 2 variabel independen yaitu googlle classroom dan gaya mengajar guru serta 1 variabel dependen yaitu motivasi belajar. Variabel google classroom memiliki 3 indikator dengan 9 butir pertanyaan. Variabel gaya mengajar guru 4 indikator dengan 30 butir pertanyaan. Variabel motivasi belajar 2 indikator dengan 10 butir pertanyaan. Disusun kedalam kuisoner online yang menggunakan skala Likert dengan skor 15. Berikut. Lamgkah pertema sebelum distrubusi kuisioner yaitu melakukan uji validitas dan reabilitas, dan diperoleh hasil yaitu :

Table 2 Hasil Uji Validitas Instrumen

\begin{tabular}{|c|c|c|c|c|c|c|c|}
\hline $\begin{array}{l}\text { Indikator } \\
\text { Gaya } \\
\text { mengajar } \\
\text { guru (X2) }\end{array}$ & & $\begin{array}{l}\text { Sub } \\
\text { Indikator }\end{array}$ & $\begin{array}{l}\text { Ketera } \\
\text { ngan }\end{array}$ & $\begin{array}{l}\text { Indikator } \\
\text { Motivasi } \\
\text { Belajar } \\
\text { (Y1) }\end{array}$ & & $\begin{array}{l}\text { Sub } \\
\text { Indikator }\end{array}$ & $\begin{array}{l}\text { Keterang } \\
\text { an }\end{array}$ \\
\hline \multirow[t]{3}{*}{$\begin{array}{l}\text { Gaya } \\
\text { Mengajar } \\
\text { Klasik }\end{array}$} & $\mathrm{X} 2.1 .1$ & Peranan Guru & $\begin{array}{l}\text { Tidak } \\
\text { Valid }\end{array}$ & \multirow[t]{3}{*}{$\begin{array}{l}\text { Motivasi } \\
\text { Instrinsik }\end{array}$} & Y1.1.1 & $\begin{array}{l}\text { Hasrat } \\
\text { untuk } \\
\text { belajar kuat }\end{array}$ & Valid \\
\hline & $\mathrm{X} 2.1 .2$ & & Valid & & Y1.1.2 & & Valid \\
\hline & $\mathrm{X} 2.1 .3$ & Isi Pelajaran & Valid & & Y1.1.3 & $\begin{array}{l}\text { Kebutuhan } \\
\text { memahami } \\
\text { materi }\end{array}$ & Valid \\
\hline
\end{tabular}


2084 Pengaruh Penggunaan Learning Management System Google Classroom dan Gaya Mengajar Guru Terhadap Motivasi Belajar Pada Pembelajaran Daring - Nungki Khunaini , Ni'matush Sholikhah DOI: https://doi.org/10.31004/edukatif.v3i5.737

\begin{tabular}{|c|c|c|c|c|c|c|c|}
\hline \multirow[t]{6}{*}{$\begin{array}{l}\text { Indikator } \\
\text { Gaya } \\
\text { mengajar } \\
\text { guru (X2) } \\
\end{array}$} & & $\begin{array}{l}\text { Sub } \\
\text { Indikator }\end{array}$ & $\begin{array}{l}\text { Ketera } \\
\text { ngan }\end{array}$ & $\begin{array}{l}\text { Indikator } \\
\text { Motivasi } \\
\text { Belajar } \\
\text { (Y1) } \\
\end{array}$ & & $\begin{array}{l}\text { Sub } \\
\text { Indikator }\end{array}$ & $\begin{array}{l}\text { Keterang } \\
\text { an }\end{array}$ \\
\hline & X2.1.4 & & Valid & & Y1.1.4 & & Valid \\
\hline & $\mathrm{X} 2.1 .5$ & $\begin{array}{l}\text { Cara } \\
\text { Penyampaian }\end{array}$ & $\begin{array}{l}\text { Tidak } \\
\text { Valid }\end{array}$ & & Y1.1.5 & $\begin{array}{l}\text { Harapan } \\
\text { untuk dapat } \\
\text { berprestasi }\end{array}$ & Valid \\
\hline & $\mathrm{X} 2.1 .6$ & & Valid & & Y1.1.6 & & Valid \\
\hline & $\mathrm{X} 2.1 .7$ & $\begin{array}{l}\text { Penyampaian } \\
\text { Materi } \\
\text { disertai } \\
\text { contoh } \\
\end{array}$ & $\begin{array}{l}\text { Tidak } \\
\text { Valid }\end{array}$ & $\begin{array}{l}\text { Motivasi } \\
\text { Ekstrinsik }\end{array}$ & Y1.2.7 & $\begin{array}{l}\text { Ingin } \\
\text { mendapat } \\
\text { penghargaa } \\
\mathrm{n}\end{array}$ & Valid \\
\hline & $\mathrm{X} 2.1 .8$ & & Valid & & Y1.2.8 & & $\begin{array}{l}\text { Tidak } \\
\text { Valid }\end{array}$ \\
\hline \multirow[t]{10}{*}{$\begin{array}{l}\text { Gaya } \\
\text { Mengajar } \\
\text { Teknologis }\end{array}$} & $\mathrm{X} 2.2 .9$ & $\begin{array}{l}\text { Peranan isi } \\
\text { pelajaran }\end{array}$ & Valid & & Y1.2.9 & $\begin{array}{l}\text { Ada } \\
\text { dukungan } \\
\text { dari } \\
\text { lingkungan }\end{array}$ & Valid \\
\hline & $\mathrm{X} 2.2 .10$ & & Valid & & Y1.2.10 & & Valid \\
\hline & $\mathrm{X} 2.2 .11$ & $\begin{array}{l}\text { Peranan siswa } \\
\text { adalah belajar } \\
\text { menggunakan } \\
\text { perangkat } \\
\text { atau media }\end{array}$ & Valid & & & & \\
\hline & $\mathrm{X} 2.2 .12$ & & Valid & & & & \\
\hline & $\mathrm{X} 2.2 .13$ & $\begin{array}{l}\text { Peranan guru } \\
\text { sebagai } \\
\text { pemandu }\end{array}$ & Valid & & & & \\
\hline & $\mathrm{X} 2.2 .14$ & & Valid & & & & \\
\hline & $\mathrm{X} 2.2 .15$ & $\begin{array}{l}\text { Isi pelajaran } \\
\text { sudah } \\
\text { diprogram }\end{array}$ & Valid & & & & \\
\hline & $\mathrm{X} 2.2 .16$ & & Valid & & & & \\
\hline & $\mathrm{X} 2.2 .17$ & $\begin{array}{l}\text { Guru hanya } \\
\text { berpegang } \\
\text { sumber media } \\
\text { yang tersedia }\end{array}$ & Valid & & & & \\
\hline & $\mathrm{X} 2.3 .18$ & & Valid & & & & \\
\hline \multirow[t]{7}{*}{$\begin{array}{l}\text { Gaya } \\
\text { Mengajar } \\
\text { Personalisasi }\end{array}$} & X2.3.19 & $\begin{array}{l}\text { Pelajaran } \\
\text { dilakukan } \\
\text { berdasarkan } \\
\text { karakteristik } \\
\text { siswa }\end{array}$ & Valid & & & & \\
\hline & $\mathrm{X} 2.3 .20$ & & Valid & & & & \\
\hline & $\mathrm{X} 2.3 .21$ & & Valid & & & & \\
\hline & $\mathrm{X} 2.3 .22$ & $\begin{array}{l}\text { Dominasi } \\
\text { Pelajaran ada } \\
\text { di siswa }\end{array}$ & Valid & & & & \\
\hline & $\mathrm{X} 2.3 .23$ & & Valid & & & & \\
\hline & $\mathrm{X} 2.3 .24$ & $\begin{array}{l}\text { Guru harus } \\
\text { mampu } \\
\text { mempunyai } \\
\text { kemampuan } \\
\text { sebagai } \\
\text { narasumber }\end{array}$ & Valid & & & & \\
\hline & $\mathrm{X} 2.3 .25$ & & Valid & & & & \\
\hline
\end{tabular}


2085 Pengaruh Penggunaan Learning Management System Google Classroom dan Gaya Mengajar Guru Terhadap Motivasi Belajar Pada Pembelajaran Daring - Nungki Khunaini , Ni'matush Sholikhah DOI: https://doi.org/10.31004/edukatif.v3i5.737

\begin{tabular}{|c|c|c|c|c|c|c|}
\hline \multirow[t]{2}{*}{$\begin{array}{l}\text { Indikator } \\
\text { Gaya } \\
\text { mengajar } \\
\text { guru (X2) }\end{array}$} & & $\begin{array}{l}\text { Sub } \\
\text { Indikator }\end{array}$ & $\begin{array}{l}\text { Ketera } \\
\text { ngan }\end{array}$ & $\begin{array}{l}\text { Indikator } \\
\text { Motivasi } \\
\text { Belajar } \\
\text { (Y1) }\end{array}$ & $\begin{array}{l}\text { Sub } \\
\text { Indikator }\end{array}$ & $\begin{array}{l}\text { Keterang } \\
\text { an }\end{array}$ \\
\hline & $\mathrm{X} 2.3 .26$ & & Valid & & & \\
\hline \multirow[t]{7}{*}{$\begin{array}{l}\text { Gaya } \\
\text { Mengajar } \\
\text { Interaksional }\end{array}$} & X2.4.27 & $\begin{array}{l}\text { Guru } \\
\text { mengedepank } \\
\text { an interaksi } \\
\text { dinamis }\end{array}$ & Valid & & & \\
\hline & $\mathrm{X} 2.4 .28$ & & Valid & & & \\
\hline & $\mathrm{X} 2.4 .29$ & $\begin{array}{l}\text { Siswa belajar } \\
\text { melalui } \\
\text { hubungan } \\
\text { dialogis }\end{array}$ & Valid & & & \\
\hline & $\mathrm{X} 2.4 .30$ & & Valid & & & \\
\hline & X2.4.31 & & Valid & & & \\
\hline & X2.4.32 & $\begin{array}{l}\text { Guru } \\
\text { mengemukak } \\
\text { an tentang } \\
\text { realita }\end{array}$ & Valid & & & \\
\hline & $\mathrm{X} 2.4 .33$ & & Valid & & & \\
\hline
\end{tabular}

Uji validitas variabel google classroom (X1) tidak dilakukan karena diadopsi penuh dari penelitian terdahulu yaitu penelitian (Ratnawati \& Sulisworo, 2021), jadi tidak perlu melakukan adanya uji validitas dan reabilitas. Hasil uji validitas variabel gaya mengajar guru (X2) terdapat 3 pertanyaan yang tidak valid, dalam hal ini hanya pertanyaan yang valid yang saja yang digunakan sebagai penelitian yaitu 30 pertanyaan. Dan hasil uji validitas variabel motivasi belajar terdapat 1 pertanyaan yang tidak valid, dalam hal ini hanya pertanyaan yang valid yang saja yang digunakan sebagai penelitian yaitu 9 pertanyaan. Dari hasil kuisioner yang disebar dengan skala Likert dengan skor 1-5 diperoleh data dalam bentuk ordinal, maka dari itu perlu tranformasi data dalam bentuk interval melalui teknik Method of Successive Interval (MSI). Setelah transformasi data ke dalam bentuk interval selanjutnya dilakukan uji asumsi klasik yaitu uji normalitas, uji heteroskedastisitas, dan uji multikolinieritas. Uji normalitas mengunakan teknik Kolmogorof-smirnov yang memperoleh hasil tingkat signifikan bernilai 0,200 > 0,05. Dari hasil yang dilakukan memperoleh hasil bahwa data terdistribusi secara normal. Kemudian uji heteroskedastisitas menggunakan teknik Scatterplot dan memperoleh hasil bahwa penyebaran titik-titik tidak berpola, titik-titik yang menyebar berada diatas dan dibawah angka 0 , titik-titik tidak berkumpul pada satu titik dan tidak membentuk pola. Dari ciri-ciri tersebut menunjukkan tidak terjadinya heteroskedastisitas. Dan uji multikolonieritas yang dilihat dari nilai VIF dan Tolerance. Jika nilai tolerance $>0,1$ dan nilai VIF $<10$ maka tidak adanya multikolinieritas, begitu pula sebaliknya. Pada uji multikolinieritas yang dilakukan, berdasarkan tabel coefficient diketahui bahwa nilai VIF Variabel X1 dan VIF Variabel X2 sebesar 1,883, dimana 1,883 < 10. Dan nilai Tolerance 0,531, dimana 0,531 $>0,1$. Dari hasil data yang diperoleh, dapat diketahui bahwa tidak adanya multikolinieritas antara variabel X1 dan variabel X2. Setelah melakukan serangkaian uji asumsi klasik, selanjutnya yaitu melakukan uji hipotesi untuk mengetahui pengaruh hubungan antar variabel secara parsial maupun secara stimultan. 
2086 Pengaruh Penggunaan Learning Management System Google Classroom dan Gaya Mengajar Guru Terhadap Motivasi Belajar Pada Pembelajaran Daring - Nungki Khunaini , Ni'matush Sholikhah DOI: https://doi.org/10.31004/edukatif.v3i5.737

\section{Hasil Uji Hipotesis}

Pengujian hipotesis menggunakan perhitungan dengan aplikasi SPSS 25 yang memperoleh hasil sebagai berikut :

Tabel 3 Hasil Uji T

\begin{tabular}{|c|c|c|c|c|c|c|}
\hline \multicolumn{7}{|c|}{ Coefficients $^{\mathbf{a}}$} \\
\hline \multirow{2}{*}{\multicolumn{2}{|c|}{ Model }} & \multicolumn{2}{|c|}{$\begin{array}{c}\text { Unstandardized } \\
\text { Coefficients }\end{array}$} & \multirow{2}{*}{$\begin{array}{c}\begin{array}{c}\text { Standardized } \\
\text { Coefficients }\end{array} \\
\text { Beta }\end{array}$} & \multirow{3}{*}{$\frac{\mathrm{t}}{2,549}$} & \multirow{3}{*}{$\begin{array}{c}\text { Sig. } \\
0,013\end{array}$} \\
\hline & & 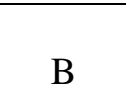 & $\begin{array}{l}\text { Std. } \\
\text { Error }\end{array}$ & & & \\
\hline 1 & (Constant) & 7,203 & 2,825 & & & \\
\hline & X1TOTAL & $-0,002$ & 0,112 & $-0,002$ & 0,015 & 0,988 \\
\hline & X2TOTAL & 0,234 & 0,037 & 0,689 & 6,309 & 0,000 \\
\hline
\end{tabular}

Sumber : data diolah oleh peneliti (2021)

Dari hasil uji t parsial menunjukkan bahwa nilai signifikansi pengaruh Google Classroom (X1) terhadap Motivasi Belajar (Y) adalah 0,988 > 0,05, dan nilai t hitung $-0,15<$ nilai $t$ tabel 1,989, dapat ditarik kesimpulan bahwa $\mathrm{H} 0$ diterima dan $\mathrm{H} 1$ ditolak. Artinya tidak terdapat pengaruh yang signfikan google classroom terhadap motivasi belajar. Berdasarkan uji $\mathrm{t}$ parsial pada tabel menunjukkan bahwa nilai signifikansi pengaruh Gaya Mengajar Guru (X2) terhadap Motivasi Belajar (Y) adalah 0,00 < 0,05, dan nilai t hitung 6,309 > nilai $\mathrm{t}$ tabel 1,989, dapat disimpulkan $\mathrm{H} 0$ diterima dan $\mathrm{H} 2$ diterima. Artinya terdapat pengaruh gaya mengajar guru terhadap motivasi belajar secara signifikan.

Tabel 4 Hasil Uji F

\begin{tabular}{|c|c|c|c|c|c|c|}
\hline \multicolumn{7}{|c|}{ ANOVA $^{\mathrm{a}}$} \\
\hline \multicolumn{2}{|c|}{ Model } & $\begin{array}{l}\text { Sum of } \\
\text { Squares }\end{array}$ & Df & $\begin{array}{l}\text { Mean } \\
\text { Square }\end{array}$ & $\mathrm{F}$ & Sig. \\
\hline \multirow[t]{3}{*}{1} & Regression & 1493,942 & 2 & 746,971 & 37,343 &, $000^{\mathrm{b}}$ \\
\hline & Residual & 1660,262 & 83 & 20,003 & & \\
\hline & Total & 3154,204 & 85 & & & \\
\hline \multicolumn{7}{|c|}{ a. Dependent Variable: YTOTAL } \\
\hline \multicolumn{7}{|c|}{ b. Predictors: (Constant), X2TOTAL, X1TOTAL } \\
\hline
\end{tabular}

Dari hasil uji F diperoleh hasil nilai signifikan pengaruh variabel Google Classroom (X1) dan Gaya Mengajar Guru (X2) terhadap Motivasi Belajar (Y) secara bersama-sama terhadap Motivasi Belajar (Y) yaitu sebesar $0,000<0,05$ dan nilai $\mathrm{f}$ hituing $37,343>\mathrm{f}$ tabel 3,11. Berdasarkan hasil yang diperoleh dapat disimpulkan H0 ditolak dan H3 diterima yang artinya terdapat pengaruh antara Google Classroom (X1) dan Gaya Mengajar Guru (X2) terhadap Motivasi Belajar (Y).

Tabel 5 Hasil Uji Koefisien Determinasi

Model Summary

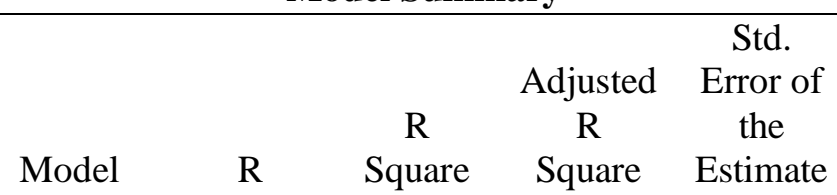

Edukatif : Jurnal Ilmu Pendidikan Vol 3 No 5 Tahun 2021 p-ISSN 2656-8063 e-ISSN 2656-8071 
2087 Pengaruh Penggunaan Learning Management System Google Classroom dan Gaya Mengajar Guru Terhadap Motivasi Belajar Pada Pembelajaran Daring - Nungki Khunaini , Ni'matush Sholikhah DOI: https://doi.org/10.31004/edukatif.v3i5.737

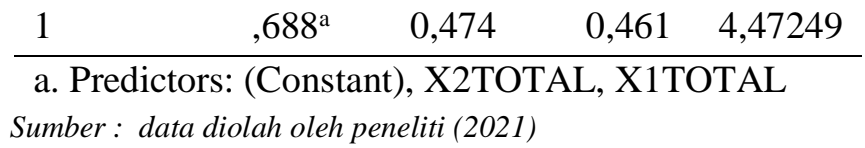

Berdasarkan analisis data yang telah dilakukan, data Adjusted $R$ Square menunjukkan nilai 0,461 atau 46,1\%. Dari data dapat diartikan bahawa pengaruh Google Classroom (X1) dan Gaya Mengajar Guru (X2) terhadap Motivasi Belajar (Y) sebesar 46,1\% dan 53,9\% dipengaruhi oleh variabel lain yang tidak diteliti oleh peneliti.

\section{Pengaruh Variabel Google Classroom terhadap Motivasi Belajar}

Dari uji analisis regresi linier berganda yang telah dilakukan yang memiliki tujuan untuk mengetahui pengaruh secara parsial Google Classroom (X1) terhadap Motivasi Belajar (Y) pada peserta didik di kelas X1 IPS MAN 2 Nganjuk diperoleh hasil bahwa Google Classroom (X1) tidak berpengaruh signifikan terhadap Motivasi Belajar (Y) pada peserta didik di kelas X1 IPS MAN 2 Nganjuk. Hasil tersebut diperoleh dari nilai $t$ hitung sebesar 0-0,15 < t tabel sebesar 1,989 atau nilai signifikansi Google Classroom terhadap Motivasi Belajar sebesar 0,988 > 0,05 sehingga menyebabkan H0 diterima dan H1 ditolak yang berarti Google Classroom tidak berpengaruh signifikan terhadap motivasi belajar pada peserta didik di kelas X1 IPS MAN 2 Nganjuk.

Berdasarkan hasil deskripsi data penelitian yang diperoleh, penggunaan Learning Management System dengan Google Classroom pada peserta didik di kelas XI IPS MAN 2 Nganjuk tergolong tinggi. Jika dilihat dari hasil data bahwa penggunaan Google Classroom pada pembelajaran pada kelas XI IPS MAN 2 Nganjuk sudah maksimal, dilihat dari kecenderungan Aspek bahasa yang mudah dipahami dan terstruktur sehingga siswa bisa menggunakan secara maksimal. Selain itu penyajian pada google classroom disertai dengan gambar dan video sehingga memudahkan siswa memahami materi yang disampaikan. Serta kemudahan yang disajikan oleh google classroom memudahkan siswa berinteraksi dengan guru dan dapat diakses secara online. Penggunaan google classroom yang sudah maksimal pada pembelajaran di X1 IPS 1 ternyata tidak memberikan pengaruh terhadap motivasi belajar siswa. Keadaan tersebut terjadi dikarenakan terjadi kemungkinan adanya ketidaktertarikan siswa dengan fitur yang ada pada Google Classroom.

Google classroom memberikan kelebihan dengan menyajikan fitur berbagai kemudahan salah satunya dalam mengakses materi ataupun tugas. Akan tetapi google classroom belum memberikan fitur yang bisa menyajikan diskusi secara tatap muka. Hal tersebut menjadi indikasi ketidaktertarikan siswa dengan google classroom sehingga tidak berpengaruh terhadap motivasi belajar. Sependapat dengan (Nurhusna, 2020) tidak adanya fitur vidio tatap muka menjadi kekurangan dalam google classroom ini karena siswa tidak dapat berdiskusi langsung secara tatap muka dengan guru. Dari pandangan guru juga menguraiakan pendapatnya, kurangnya fitur yang dapat digunakan untuk menyampaikan materi secara langsung sehinga siswa merasa kesulitan dalam memahami materi secara langsung (Nirmala et al., 2020). Seperti peneltian yang dilakukan oleh Azhar \& Iqbal (2018) yang mengungkapkan Google Classroom tidak efektif digunakan dalam pembelajaran, karena fiturnya yang masih kurang lengkap seperti hanya sebatas pengunduhan materi dan pengumpulan tugas, belum ada fitur yang bisa digunakan untuk streaming. Hasil dari penelitian ini berlawanan dengan penelitian Rikizaputra et al (2020) yang menujukkan adanya pengaruh positif dan signifikan Google Classroom terhadap Motovasi Belajar. Sedangkan berdasarkan hasil peneilitian ini menunjukkan bahwa tidak ada pengaruh yang positif dan signifikan Google Classroom terhadap Motivasi Belajar.

\section{Pengaruh Variabel Gaya Mengajar terhadap Motivasi Belajar}

Dari hasil uji analisis regresi linier berganda yang telah diujikan yang memiliki tujuan agar dapat mengetahui pengaruh secara parsial Gaya Mengajar Guru (X2) terhadap Motivasi Belajar (Y) pada peserta 
2088 Pengaruh Penggunaan Learning Management System Google Classroom dan Gaya Mengajar Guru Terhadap Motivasi Belajar Pada Pembelajaran Daring - Nungki Khunaini , Ni'matush Sholikhah DOI: https://doi.org/10.31004/edukatif.v3i5.737

didik kelas X1 IPS MAN 2 Nganjuk diperoleh hasil bahwa Gaya Mengajar Guru (X2) mempumyai pengaruh signifikan dan positif terhadap Motivasi Belajar (Y) terhadap kelas X1 IPS MAN 2 Nganjuk. Hasil tersebut diperoleh dari nilai $\mathrm{t}$ hitung sebesar 6,309 > t tabel sebesar 1,989 atau nilai signifikansi Google Classroom terhadap Motivasi Belajar sebesar 0,00 $<0,05$ sehingga menyebabkan $\mathrm{H} 0$ ditolak dan $\mathrm{H} 2$ ditoerima yang berarti Gaya Mengajar yang diterapkan Guru mempunyai pengaruh signifikan dan positif terhadap Motivasi Belajar pada peserta didik X1 IPS MAN 2 Nganjuk.

Berdasarkan hasil deskripsi data penelitian yang diperoleh, penggunaan gaya mengajar guru pada siswa X1 IPS MAN 2 Nganjuk tergolong tinggi. Jika dilihat dari hasil data yang diperoleh pada variabel gaya mengajar guru, penggunaan variasi gaya mengajar oleh guru sudah maksimal pada kegiatan pembelajaran dan didominasi oleh gaya mengajar interaksional serta gaya mengajar personalisasi. Hal tersebut diketahui dari kecenderungan siswa yang mampu berkomunikasi dengan baik dalam kegiatan pembelajaran, secara tidak langsung guru berhasil menerapkan gaya mengajar interkasional didalam kelas dengan melatih siswa untuk berdiskusi dengan sesama ataupun mengungkapkan pendapatnya secara lisan didepan kelas. Selain itu kecenderungan siswa juga mampu berperan aktif didalam kelas, hal ini menandakan bahwa guru mampu menerapkan gaya mengajar personalisasi pada keberlangsungan kegiatan belajar mengajar secara tepat dengan memahami karakteristik yang ada pada individu siswa, tidak hanya itu guru juga menjadi narasumber yang baik sehingga dapat memicu siswa untuk aktif bertanya untuk menggali informasi yang tidak diketahui oleh siswa. Guru merupakan bagian dari faktor yang memiliki dampak peningkatan motivasi belajar pada siswa oleh karena itu peran seorang guru dalam kegiatan belajar mengajar sangatlah penting (Putri et al., 2019). Ketika guru menggunakan gaya mengajar yang tepat pada siswa, akan menumbuhkan suasana pembelajaran yang nyaman dan menyenangkan, tentunya hal tersebut akan berdampak terhadap semangat belajar siswa dan menumbuhkan motivasi belajar terhadap siswa. Seperti halnya pada penelitian ini, penggunaan gaya mengajar dengan tepat yang dominasi oleh gaya mengajar interkasional dan personalisasi dapat mempengaruhi motivasi belajar siswa. Oleh sebab itu gaya mengajar yang diterapkan guru memiliki pengaruh yang positif dan signifikan terhadap motivasi belajar.

Hasil penelitian ini sependapat dengan Putri et al (2019) yang berpendapat bahwa guru adalag faktor internal yang dapat memberikan dampak pengingkatan pada motivasi belajar siswa, salah satunya upaya yang dilakukan guru dalam pembelajaran yaitu gaya mengajar. Gaya mengajar yang diterapkan guru memberikan pengetahuan kepada siswa, membentuk karakter siswa, membimbing perilaku dan kepribadian siswa. terbentuknya suasana belajar mengajar yang menyenangkan dan dapat memicu ketertarikan siswa dan memberikan dampak kemudahan terhadap siswa dalam memahami materi yang disampaikan merupakan keberhasilan dalam mengajar (Al Khumaero, 2017). Sependapatan dengan penelitian yang Cahya (2020) yang mengungkapan bahwa penggunaan gaya mengajar guru yang tepat dapat memiliki dampak pengaruh signifikan terhadap motivasi belajar suswa.

\section{Pengaruh Variabel Google Classroom dan Gaya Mengajar Guru terhadap Motivasi Belajar}

Berdasarkan uji analisis regresi linier berganda yang telah dilakukan yang bertujuan untuk mengetahui pengaruh secara stimultan Google Classroom (X1) dan gaya Mengajar Guru (X2) terhadap Motivasi Belajar (Y) pada siswa kelas X1 IPS MAN 2 Nganjuk diperoleh hasil bahwa Google Classroom (X1) dan Gaya Mengajar Guru (X2) secara stimultan memiliki signifikan terhadap Motivasi Belajar (Y) terhadap kelas X1 IPS MAN 2 Nganjuk. Hasil tersebut diperoleh dari nilai F hitung sebesar 37,343 > F tabel sebesar 3,11 atau nilai signifikansi google classroom dan gaya mengajar guru terhadap motivasi belajar sebesar $0,000<0,05$ sehingga menyebabkan H0 ditolak dan H3 diterima yang berarti bahwa Google Classroom dan gaya mengajar guru secara simultan mempunyai pengaruh signifikan terhadap motivasi belajar pada peserta didik X1 IPS MAN 2 Nganjuk. Google Classroom dan gaya mengajar guru secara bersama-sama memiliki pengaruh yang signifikan terhadap Motivasi Belajar pada peserta didik XI IPS MAN 2 Nganjuk sebesar 46,1\% yang menunjukkan bahwa 53,9\% dipengaruhi oleh variabel lain yang tidak diketahui. 
2089 Pengaruh Penggunaan Learning Management System Google Classroom dan Gaya Mengajar Guru Terhadap Motivasi Belajar Pada Pembelajaran Daring - Nungki Khunaini , Ni'matush Sholikhah DOI: https://doi.org/10.31004/edukatif.v3i5.737

Sejuah ini belum ada penelitian yang sama yang menyatakan bahwa adanya pengaruh signifikan Google Classroom dan gaya mengajar guru terhadap motivasi belajar secara bersama-sama. Terdapat penelitian yang sama namun hanya ada pengaruh secara parsial dari masing-masing variabel yaitu penelitian yang dilakukan oleh (Rikizaputra et al., 2020) mengemukakan adanya pegaruh yang positif dan signifikan antara Penggunaa google classroom terhadap Motivasi Belajar. Dan penelitian yang dilakukan oleh Putri et al. (2019) yang mengungkapkan adanya sebuah pengaruh yang positif dan signifikan antara gaya mengajar yang digunakan oleh guru terhadap motivasi belajar.

Penggunaan Google Classroom pada kegiatan pembelajaran dapat memberikan dampak meningkatnya motivasi belajar pada siswa, hal tersebut dikarenakan dengan menggunakan google classroom guru lebih mudah dalam mendistribusikan tugas yang diberikan dan memberikan nilai tugas kepada siswa begitupula siswa juga lebih mudah dalam mengumpulkan tugas yang telah diberikan (Rikizaputra et al., 2020). Begitupula dengan gaya mengajar guru, peran guru memiliki dampak terhadap adanya peningkatan motivasi belajar dalam pembelajaran salah satunya yaitu penerapan gaya mengajar yang digunakan tepat yang menyersuaikan kondisi siswa (Putri et al., 2019). Maka dari itu jika dari dua variabel tersebut digunakan dalam waktu yang sama akan dapat memberikan dampak peningkatan motivasi belajar. Hal tersebut selaras dengan hasil penelitian ini dimana google classroom dan gaya mengajar guru jika diterapkan dalam waktu yang sama secara dapat berpengaruh terhadap motivasi belajar.

\section{KESIMPULAN}

Berdasarkan hasil penelitian serta analisis data yang telah dilakukan, memperoleh hasil kesimpulan bahwa : 1) Tidak terdapat pengaruh positif dan signifikan secara parsial antara variabel Google Classroom terhadap Motivasi Belajar siswa kelas XI IPS MAN 2 Nganjuk, 2) adanya pengaruh yang positif dan signifikan secara parsial antara variabel gaya mengajar guru terhadap motivasi belajar siswa kelas XI IPS MAN 2 Nganjuk 3) adanya pengaruh yang signifikan secara stimultan dari variabel google classroom dan gaya mengajar guru terhadap motivasi belajar siswa kelas XI IPS MAN 2 Nganjuk. Dari hasil tersebut adapun penggunaan gaya mengajar yang sebaiknya digunakan pada kegiatan pembelajaran di kelas XI IPS MAN 2 Nganjuk yaitu gaya mengajar interaksional dan personalisasi, karena dari hasil penelitian menunjukkan bahwa siswa mampu berperan aktif didalam kelas dan mampu berinteraksi dengan baik ketika gaya mengajar tersebut diterapkan.

\section{DAFTAR PUSTAKA}

al Khumaero, L. S. A. (2017). Pengaruh Gaya Mengajar Guru, Disiplin Belajar, Dan Teman Sebaya Terhadap Prestasi Belajar. 6(3), 698-710.

Alfina, O. (2020). Penerapan Lms-Google Classroom Dalam Pembelajaran Daring Selama Pandemi Covid-19. Majalah Ilmiah Methoda, 10(1), 38-46. Https://Doi.Org/10.46880/Methoda.V10i1.537

Ali, M. (2004). Guru Dalam Proses Gaya Mengajar. Sinar Batu Algesindo.

Astutie, C. S. A. (2003). Pengaruh Gaya Mengajar Guru Dan Gaya Belajar Siswa Terhadap Hasil Belajar Mata Pelajaran Ekonomi Di Kelas X Sma Negeri 18 Surabaya. 20, 1-15.

Azhar, K. A., \& Iqbal, N. (2018). Effectiveness Of Google Classroom: Teachers' Perceptions. Prizren Social Science Journal, 2(2), 52-66.

Cahya, L. (2020). Pengaruh Gaya Mengajar Guru Terhadap Motivasi Belajar Siswa Kelas 3 Sdn Ngebruk 01 Kecamatan Poncokusumo Kabupaten Malang. Seminar Nasional Pgsd Unikama, 4, 461-471. Https://Conference.Unikama.Ac.Id/Artikel/ 
2090 Pengaruh Penggunaan Learning Management System Google Classroom dan Gaya Mengajar Guru Terhadap Motivasi Belajar Pada Pembelajaran Daring - Nungki Khunaini , Ni'matush Sholikhah DOI: https://doi.org/10.31004/edukatif.v3i5.737

Daheri, M., Juliana, D., \& Amda, A. D. (2020). Efektifitas Whatsapp Sebagai Media Belajar Daring. 4(4), 775-783. Https://Doi.Org/10.31004/Basicedu.V4i4.445

Destyana, V. A., \& Surjanti, J. (2021). Efektivitas Penggunaan Google Classroom Dan Motivasi Belajar Terhadap Hasil Belajar Peserta Didik Mata Pelajaran Ekonomi. Edukatif: Jurnal Ilmu Pendidikan, 3(3), 1000-1009. Https://Doi.Org/Https://Doi.Org/10.31004/Edukatif.V3i3.507

Djauhari, A. (2016). Pengaruh Gaya Mengajar Guru Dan Kebiasaan Belajar Terhadap Hasil Belajar ( Studi Pada Mata Pelajaran Ips Peserta Didik Di Smp Negeri Satu. Jurnal Penelitian Dan Pendidikan Ips (Jppi), 10(3), 310-321.

Emda, A. (2017). Kedudukan Motivasi Belajar Siswa Dalam Pembelajaran. Lantanida Journal, 5(2), 93-196.

Fitriyani, Y., Fauzi, I., \& Sari, M. Z. (2020). Motivasi Belajar Mahasiswa Pada Pembelajaran Daring Selama Pandemik Covid-19. Jurnal Kependidikan: Jurnal Hasil Penelitian Dan Kajian Kepustakaan Di Bidang Pendidikan, Pengajaran Dan Pembelajaran, 6(2), 165-175.

Ghozali, I. (2013). Aplikasi Analisis Dengan Program Spss. Badan Penerbit Universitas Diponegoro.

Harahap, H. S., Hrp, N. A., Nasution, I. B., Harahap, A., Harahap, A., \& Harahap, A. (2021). Hubungan Motivasi Berprestasi, Minat Dan Perhatian Orang Tua Terhadap Kemandirian Siswa. Edukatif: Jurnal Ilmu Pendidikan, 3(4), 1133-1143. Https://Doi.Org/Https://Doi.Org/10.31004/Edukatif.V3i4.463

Kurniawan, A. (2018). Metodologi Penelitian Pendidikan (Pertama). Pt Remaja Rosdakarya.

Nirmala, I. D., Srisulistiowati, D. B., \& Rejeki, S. (2020). Analisis Pemanfaatan ( Lms ) Google Classroom Sebagai Media Digitalisasi Pembelajaran Jarak Jauh Di Era Pandemi Covid 19. 1(2), 173-186.

Nurhusna. (2020). Google Classroom Sebagai Media Pembelajaran Pada Mata Kuliah Teks Bahasa Indonesia. Prosiding Seminar Daring Nasional: Pengembangan Kurikulum Merdeka Belajar, 52-57. Https://Ejournal.Unib.Ac.Id/Index.Php/Semiba/Issue/View/956/

Putri, V. J., Subarno, A., \& Susantiningrum. (2019). Pengaruh Gaya Mengajar Guru Dan Perhatian Orang Tua Terhadap Motivasi Belajar Siswa Di Smk Batik 1 Surakarta. Jurnal Informasi Dan Komunikasi Administrasi Perkantoran, 3, 32-39.

Rahman, M. H. (2016). Pengaruh Model Pembelajaran Dan Gaya Mengajar Guru Tehadap Prestasi Belajar Siswa Pada Mata. 10(3), 337-344.

Ratnawati, H., \& Sulisworo, D. (2021). The Effectiveness Of E-Learning Based On Lms By Google Classroom With Discovery Learning Strategy For High School In The Topic Of Fluid Static. Jurnal Penelitian Pendidikan Fisika, 6(2), 137-145. Https://Doi.Org/10.36709/Jipfi.V6i2.17162

Rikizaputra, Sulastri, \& Hanna. (2020). Pengaruh E-Learning Dengan Google Classroom Terhadap Hasil Dan Motivasi Belajar Biologi Siswa. Lectura: Jurnal Pendidikan, 11(1), 106-118. Https://Doi.Org/10.31849/Lectura.V11i1.3760

Sadirman. (2016). Interaksi Dan Motivasi Belajar Mengajar. Rajawali Pers.

Sedarmayanti, \& Hidayat, S. (2011). Metode Penelitian. Bandung: Mandar Maju.

Shaharanee, I. N. M., Jamil, J. M., \& Rodzi, A. S. S. M. (2016). The Application Of Google Classroom As A Tool For Teaching And Learning. Journal of Telecommunication, Electronic And Computer Engineering, 8(10), 5-8.

Suprihatin, S. (2015). Upaya Guru Dalam Meningkatkan Motivasi Belajar Siswa. 3(1), 73-82. 